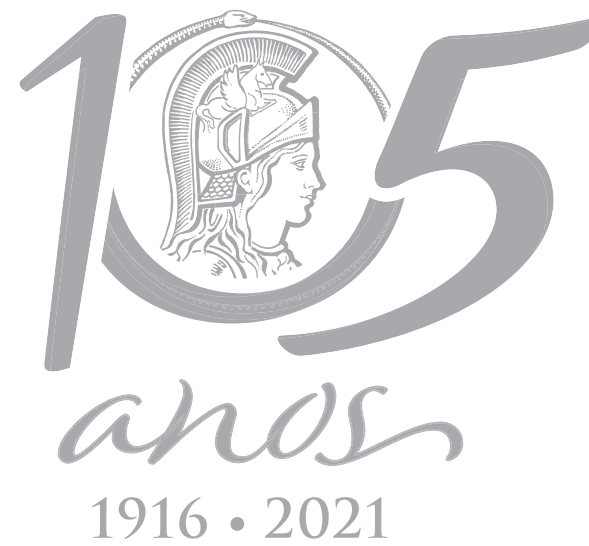

$1916 \cdot 2021$

\title{
ECOSYSTEMS
}

\section{Monitoring the anthropogenic impacts in Admiralty Bay using meiofauna community as indicators (King George Island, Antarctica)}

\author{
PAULA F. GHELLER \& THAIS N. CORBISIER
}

\begin{abstract}
Activities at the Brazilian Antarctic Station (EACF) may cause damage to surrounding environment. Meiofauna was used to evaluate this impact. One area possibly impacted by the stations' presence (CF) and a reference area (BP) were compared. Sediment samples for meiofauna and environmental variables were obtained in two periods, at two sites and depths in each area. Densities were higher at 20-30m and nematodes were the dominant taxa (90\%). Nematode densities ranged from 1,278 \pm 599 (BP1 50-60m) to 16,021 $\pm 12,298$ ind.10 $\mathrm{cm}^{-2}$ (BP2 20-30m). A total of 68 genera were found. Sample richness ranged from 8 to 26 and diversity from 1.4 to 3.6 bits/ind, both being higher at BP 50-60m, where dominance of epistrate feeders was lower. Selective and non-selective deposit feeders were codominant with similar proportions. Maturity index was high and constant between samples. Aponema, Sabatieria, Daptonema, Dichromadora and Halalaimus were dominant, with higher densities at 20-30m. In contrast, Actinonema, Molgolaimus, Oxystomina and Marylynnia were more abundant at 50-60m. Differences in meiofauna community were found mainly between depths, but not between sites or periods, suggesting no anthropogenic impact. Nevertheless, lower Nematoda diversities and maturity index at 50-60m in CF when compared to BP may indicate a possible anthropogenic effect near EACF.
\end{abstract}

Key words: Martel Inlet, Antarctic, sewage, pollution effects, meiobenthos, Nematoda.

\section{INTRODUCTION}

Impacts of human activities on the Antarctic environment date back to the 18th century with the arrival of the first exploring and sealing expeditions. Since then, intensity and scale of human activities have continued to increase. Regardless the nature of the activity, human presence in Antarctica depends on the use of fossil fuels and imported construction materials, produces wastes, and interacts with landscapes, flora, and fauna (Tin et al. 2009 and references therein). Scientific, logistic and tourism activities in Antarctica have introduced anthropogenic compounds in otherwise pristine areas (Martins et al. 2004). Main source of contamination is sewage from Antarctic stations that can be released into the marine coastal environment and may cause alteration in benthic community structure (Lenihan et al. 1990, Conlan et al. 2004, Stark et al. 2003, 2020). Local sources of contamination to the marine environment near the Brazilian Antarctic Station (hereafter called just EACF) include chemical compounds disposed of through the sewage system, from melt-water percolation through fuel contaminated soils and from fuel combustion. Chemicals studied near EACF include fecal sterols and linear alkylbenzenes (Montone et al. 2010, Martins et al. 2012, 2014), heavy metals (Santos et al. 2005, Trevisani et al. 2018), aliphatic (AH) and polycyclic aromatic 
hydrocarbons (PAH) (Bícego et al. 2009, Martins et al. 2004, 2005, 2010). Contamination level were in general low and restricted to the vicinity of EACF, however the Scientific Committee for Antarctic Research (SCAR) recommends continued studies to evaluate the impact of activities in the area.

Meiofauna is a group of small benthic metazoans retained between 500 and 38 $\mu \mathrm{m}$ sieves (Mare 1942). Advantages of using meiofauna to monitor anthropogenic effects or environmental changes include their ubiquitous presence, high abundance, close relationship and dependence with sediment, low mobility, short life cycles, no pelagic larval phase, which contribute for a quick response to local changes (Coull \& Chandler 1992). Recent studies have shown the usefulness of nematodes as possible cost-efficient and effective bioindicator, though many challenges have yet to be overcome, especially related to limited number of experts in marine nematology (Ingels et al 2014, Ridall \& Ingels 2021).

Focusing on the Antarctic shallow coastal zone (up to $200 \mathrm{~m}$ ), there are few studies about meiofauna from Admiralty Bay (Skowronski et al 1998, Skowronski \& Corbisier 2002, Corbisier et al. 2010), in Marian Cove (Bang et al. 2005, Hong et al. 2011) and in Potter Cove (Pasotti et al. 2012, 2014) in King George Island. Also, in West Antarctica Peninsula, there are studies from Factory Cove in Signy Island (Lee et al. 2001a, Vanhove et al. 1998, 2000) and from Ryder Bay in Adelaide Island (Fonseca et al. 2017). While in East Antarctica, meiofauna from the area near Casey Station was studied (Stark et al. 2020), and in the Ross Sea, from Terra Nova Bay (Danovaro et al. 1999). In deeper areas, meiofauna has been studied in the Ross Sea (Fabiano \& Danovaro 1999), in the Weddell Sea including Larsen iceshelf (Vanhove et al. 1995, 1999, 2004, Raes et al. 2010, Hauquier et al. 2011,
Rose et al. 2015) and in the East Antarctica (Pantó et al. 2021). Common environmental factors affecting meiofauna community structure are mainly sediment grain size, food availability and physical disturbance (Coull 1988 and references therein). Those studies show these factors are also important in Antarctic shallow coastal zone, however there is large spatial variability in meiofauna distribution and structure, and a pattern is not always clear.

Admiralty Bay (King George Island) is one of the most studied marine ecosystems of Antarctica, mainly due to the Polish and Brazilian Antarctic Programs, which have run scientific studies in the area for ca. 40 years. Past data, especially those related to the benthic system, have been gathered and synthesized, resulting in a list of almost 1300 benthic species. However, some taxa, like Nematoda, are still not sufficiently studied (Sicinski et al. 2011), despite being the dominant and most abundant taxa in meiofauna, representing more than $90 \%$ of organisms (Skowronski \& Corbisier 2002). Nematoda may be an excellent indicator of environmental change in Antarctic coastal waters (Stark et al. 2017, 2020). The aim of this study is to compare meiofauna and nematodes community structures at the area off the Brazilian Antarctic Station with a reference area to search for alteration that might have been caused by human activities. We also set a baseline for long term monitoring of meiofauna in the area most influenced by Brazilian research and logistics activities in Antarctica.

\section{Study area}

The study area is in Martel Inlet, which is in Admiralty Bay (AB), King George Island (KGI), located in the South Shetland Islands, Antarctic Peninsula (Figure 1). Admiralty Bay, the largest bay in KGI, has three inlets: Mackellar and Martel located in its northern portion, and 


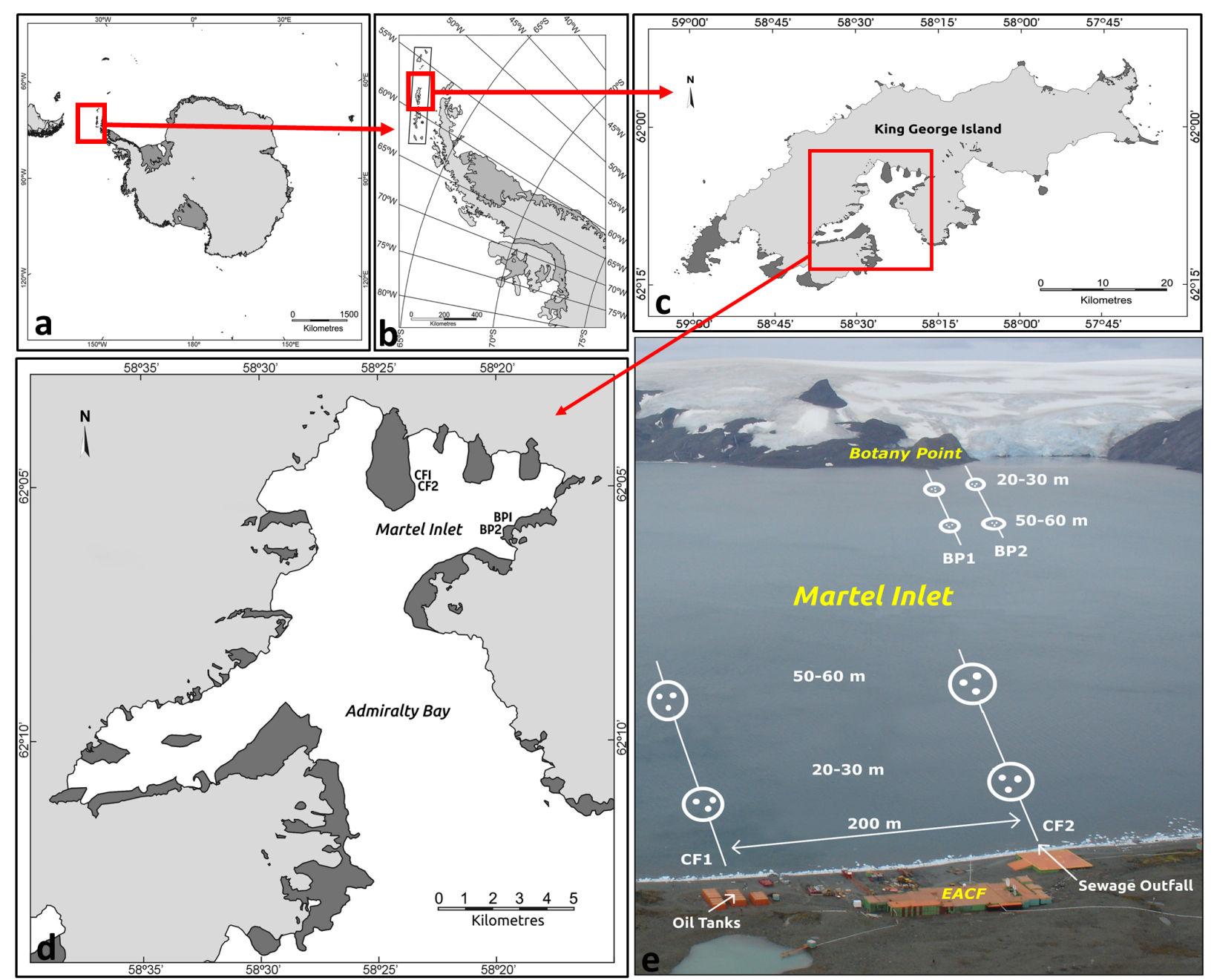

Figure 1. Antarctica (a) with detail of the South Shetlands Island in the Antarctic Peninsula (b), where King George Island (c) is located. Sampling sites were located in Martel Inlet in Admiralty Bay (d). Schematic view of the sampling sites (e). Maps modified from Simões et al. 2004. Photo credits: Thais Santos

Ezcurra located in its western portion. The bay is a large fjord of tectonic origin with a maximum depth of $535 \mathrm{~m}$ and connects with the Bransfield Strait through wide opening facing south. Tidal currents constitute the main factor responsible for this water mixing and may reach $50 \mathrm{~ms}^{-1}$ (Sicinski et al. 2011). Variation in water temperature and salinity is slight and does not affect the circulation in $A B$. Temperature and salinity range from -0.2 to $5.3^{\circ} \mathrm{C}$ and 32.9 to 34.2, on the surface, and from 33.8 to 34.3 and -0.4 to $0.9^{\circ} \mathrm{C}$, in the bottom (Jazdzewski et al. 1986). Sediment is mainly composed by pebbles and gravels, changing to sandy muds or muds towards deeper areas (Nonato et al. 1992).

Admiralty Bay hosts several research stations operated by Brazil, Poland, Peru, the United States of America, and Ecuador, being designated an Antarctic Specially Managed Area (ASMA no.1) by the Antarctic Treaty System Consultative Meeting in 1996 (ATCM XXVIII 2005) to manage the impacts of numerous nations' activities in the area (Montone et al. 2013).

The Brazilian Antarctic Station Comandante Ferraz(EACF)was established in 1984 and a sewage treatment plant was implemented in 1995/96. 
Fecal sterols (coprostanol + epicoprostanol), as indicator of sewage contribution to the sediment, was monitored since 1997/98, and background levels for the area was established as $0.19 \mu \mathrm{g} . \mathrm{g}$ ${ }^{-1}$ (Montone et al. 2010). At EACF in the summer 1999-2000 values of fecal sterols were around background levels, expect at the sewage outfall, where values of up to $14 \mu \mathrm{g} . \mathrm{g}^{-1}$ were measured (Martins et al. 2005). Values of fecal sterols levels gradually increased until 2003/2004, to a maximum of $0.95 \mu \mathrm{g} . \mathrm{g}^{-1}$ at a $20 \mathrm{~m}$ distant from the sewage outfall, as a result of the twofold increment of human population at EACF over time and lack of improvements in the treatment system (Martins et al. 2012). However, in the summer 2005/2006 a new system treatment was installed and fecal sterols levels gradually decreased in following years, returning to 0.17 $\mu \mathrm{g} . \mathrm{g}^{-1}$, near the background level (Martins et al. 2012). Therefore, by the time sampling was performed for the present study, in the summer $2004 / 2005$, levels of fecal sterols were probably at its highest for the region near EACF, as well as other contaminants from sewage origin, which is an ideal scenario for investigating if the meiofauna community was influenced by this impact.

\section{MATERIALS AND METHODS}

\section{Sampling}

Sampling was undertaken in Martel Inlet, Admiralty Bay (King George Island, Antarctica) (Figure 1a-e) in two periods. The first period (I) was conducted in late spring 2004 (November 23 to December 12), while the second period (II) was in middle summer 2005 (January 22 to February 09). Two areas (CF and BP) were compared, with two sites (200 m apart) and two depth (20-30 m and 50-60 m) in each. CF was located off EACF, under anthropogenic influence as described above, with sites CF1- near the oil tanks and
CF2- near the sewage outfall. BP, Botany Point, was chosen as a reference area at the opposite margin of Martel Inlet, with sites BP1 and BP2 (Figure 1e). Distance between areas was $3.5 \mathrm{Km}$.

Sediment from each site and depth was sampled with a $0.063 \mathrm{~m}^{2}$ mini box-corer in triplicate (Echeverría et al. 2009). From each box corer, one sediment sample was obtained for meiofauna with a cylindrical copper corer (area of $4.9 \mathrm{~cm}^{2}-5.0 \mathrm{~cm}$ deep) and formalin preserved. From each box core were also obtained two sediment sample for phytopigments biomasses, and another one for grain size, carbonates, and organic matter percentage, which were frozen for further analysis. Grain size was determined according to Suguio (1973) and phytopigments according to Plante-Cuny (1978). The two subsamples obtained for phytopigments from each box-corer were averaged and the mean value used in the analyses as a replicate. Detailed methods and discussion on phytopigments can be found on Skowronski et al. (2009). Carbonate percentages were obtained by weight difference, before and after $\mathrm{HCl}$ dissolution (Gross 1971). Organic matter percentages were obtained by weight difference, before and after combustion at $450^{\circ} \mathrm{C}$ for 12 hours (Byers et al. 1978). Meiofauna samples were stained with Rose Bengal and washed through $0.5 \mathrm{~mm}$ and $0.063 \mathrm{~mm}$ mesh sieves. Animals retained between these sieves were sorted to higher taxonomic groups and counted. For nematode identification, 100 specimens from two replicates only were randomly picked out and mounted on glass slides following the paraffin-glycerin protocol (Seinhorst 1959, De Grisse 1969). Genus were identified to genus level with pictorial keys (Warwick et al. 1998) and consulting the online NEMYS database (Bezerra et al. 2021). Proportion of each genera identified was multiplied by total number of nematodes in each sample and mean densities in $10 \mathrm{~cm}^{2}$ were calculated. 


\section{Data analysis}

To investigate significant differences between sites in environmental variables and meiofauna densities Kruskal-Wallis analysis (KW, p < 0.05), and in the case of significant results a posteriori Student-Newman-Keuls test was employed. Between depths and periods, Mann-Whitney tests were used (MW, p < 0.05) (BIOESTAT v4, Ayres et al. 2005). A Principal Component analysis (PCA) was used to explore differences in normalized environmental data between sites and periods (PRIMER v6, Clarke \& Gorley 2006). Non-metric multidimensional scaling (nMDS) was done for the 10 main meiofauna taxa mean densities. Densities were square root transformed and Bray-Curtis resemblance measure was applied. Hierarchical cluster analysis was used to explore Nematoda genera composition. For this, abundance data of the 30 dominant genera (across variables: Q-mode) in all sites, depths, and periods (across samples: R-mode) was fourth root transformed, and two resemblance matrixes using Bray-Curtis similarity were calculated (between genera and between samples). Based on each matrix, a cluster was plotted as a dendrogram with group average linkage and SIMPROF test with significance level of 5\% (PRIMER v6, Clarke \& Gorley 2006). Clusters for genera and sites were analyzed together with a scaled density data. Main genera had overall nematode densities higher than 200 ind. $10 \mathrm{~cm}^{-2}$ and summed up to $98 \%$ of nematodes.

To test differences in meiofauna taxa community and Nematoda genus composition between groups of samples, multivariate permutational analysis of similarity (ANOSIM) were used considering only areas and depths ( 4 groups, CF 20-30 m, CF 50-60 m, BP 20-30 m and BP 50-60 m). To identify taxa that discriminate between groups, SIMPER dissimilarity analysis was done (PRIMER v6, Clarke \& Gorley 2006).
Nematode trophic groups were defined based on buccal morphology according to Wieser (1953), as selective deposit feeders (1A), non-selective deposit feeders (1B), epistrate feeders (2A) and predators/carnivores (2B). The Index of Trophic Diversity (ITD), based on the proportion of each trophic group, was calculated following Heip et al. (1985). The Maturity Index (MI) was determined for the nematode assemblage as the weighted average of the individual genera colonizer-persister values (cp) (Bongers et al. 1991). Richness (S- number of genera and d-Margalef), Shannon's diversity $\left(H^{\prime} \log 2\right)$ and Pielou's evenness $(J)$ indices were calculated to describe the nematode genus assemblage structures (PRIMER v6, Clarke \& Gorley 2006). Spearman rank was applied to search for correlation between biological and environmental variables with the free statistical software R v.4.0.1 (R Core Team 2021) and package "psych" v.2.1.6 (Revelle 2021).

\section{RESULTS}

\section{Environmental characteristics}

Sediments were very poorly sorted, mostly classified as silt (mean diameter between 2.8 to 5.4 phi). Fractions of silt, clay and gravel prevailed over sand fractions. Sediments were similar between areas and sites (KW results were not significant). Between depths, there was higher contribution of sand fractions at 20-30 $\mathrm{m}$, and of silt and clay at 50-60 m, which was significant for very fine sand at all sites, and for fine sand at most sites, except BP1 I and CF1 II (MW, p < 0.05) (Supplementary Material- Table $\mathrm{SI}$ ). Between periods, relative contribution of coarser fractions was lower in middle summer, especially at CF2 50-60 m, were gravel, coarse, medium, and fine sand were significantly lower in summer than in spring. 
Percentages of carbonates were higher at $20-30 \mathrm{~m}$ (from $0.3 \pm 0.5 \%$ to $3.2 \pm 1.0 \%$ ) than at $50-60 \mathrm{~m}$ (from $0.0 \pm 0.0 \%$ to $0.5 \pm 0.9 \%$ ), but differences between depth were significant only in BP1 I, BP1 II and BP2 II (Table SI). Differences were not significant between areas, sites, or periods.

Organic matter percentages were higher at $20-30 \mathrm{~m}$ (from $1.3 \pm 0.13 \%$ to $4.2 \pm 1.2 \%$ ) than at $50-60 \mathrm{~m}$ (from $1.1 \pm 0.2 \%$ to $2.9 \pm 0.3 \%$ ), but only significantly different at CF1 I and CF2 II (Table $\mathrm{SI}$ ). Comparing between periods, at 20-30 m there were no differences, however, at 50-60 m, CF2 and BP1 percentages were higher in summer than in spring.

Phytopigments biomass was described by Skowronski etal. (2009). Similarvalues were found between areas and sites and varied from $19 \pm 13$ to $87 \pm 54 \mathrm{mg} \cdot \mathrm{m}^{-2}$ for chlorophyll-a, and from $47 \pm$ 15 to $176 \pm 127 \mathrm{mg} \cdot \mathrm{m}^{-2}$ for phaeopigments at 20-30 $m$. At 50-60 m values were lower and varied from
$1 \pm 0.4$ to $9 \pm 9 \mathrm{mg} \cdot \mathrm{m}^{-2}$ for chlorophyll-a, and from $38 \pm 11$ to $115 \pm 53 \mathrm{mg} \cdot \mathrm{m}^{-2}$ for phaeopigments. This difference between depths was significant for chlorophyll-a at all sites and periods (except BP2 I) and for phaeopigments only at CF1 I, BP2 I and CF1 II. Comparing at each depth, no significant difference was found between periods (Table SI).

In the principal components analysis (PCA), the first axis explained 55\% of data variation, segregating samples with higher amounts of sands and carbonates to the left (BP 20-30 m) from those with finer sediments to the right (all 50-60 m samples), while CF 20-30 m samples were intermediate (Figure 2). The second axis explained only $21 \%$ of data variation, mainly segregating samples with higher chlorophyll-a biomass and organic matter above (CF 20$30 \mathrm{~m}$ ), from those with lower concentrations below (all 50-60 m samples). The vectors of the environmental variables displaced in the

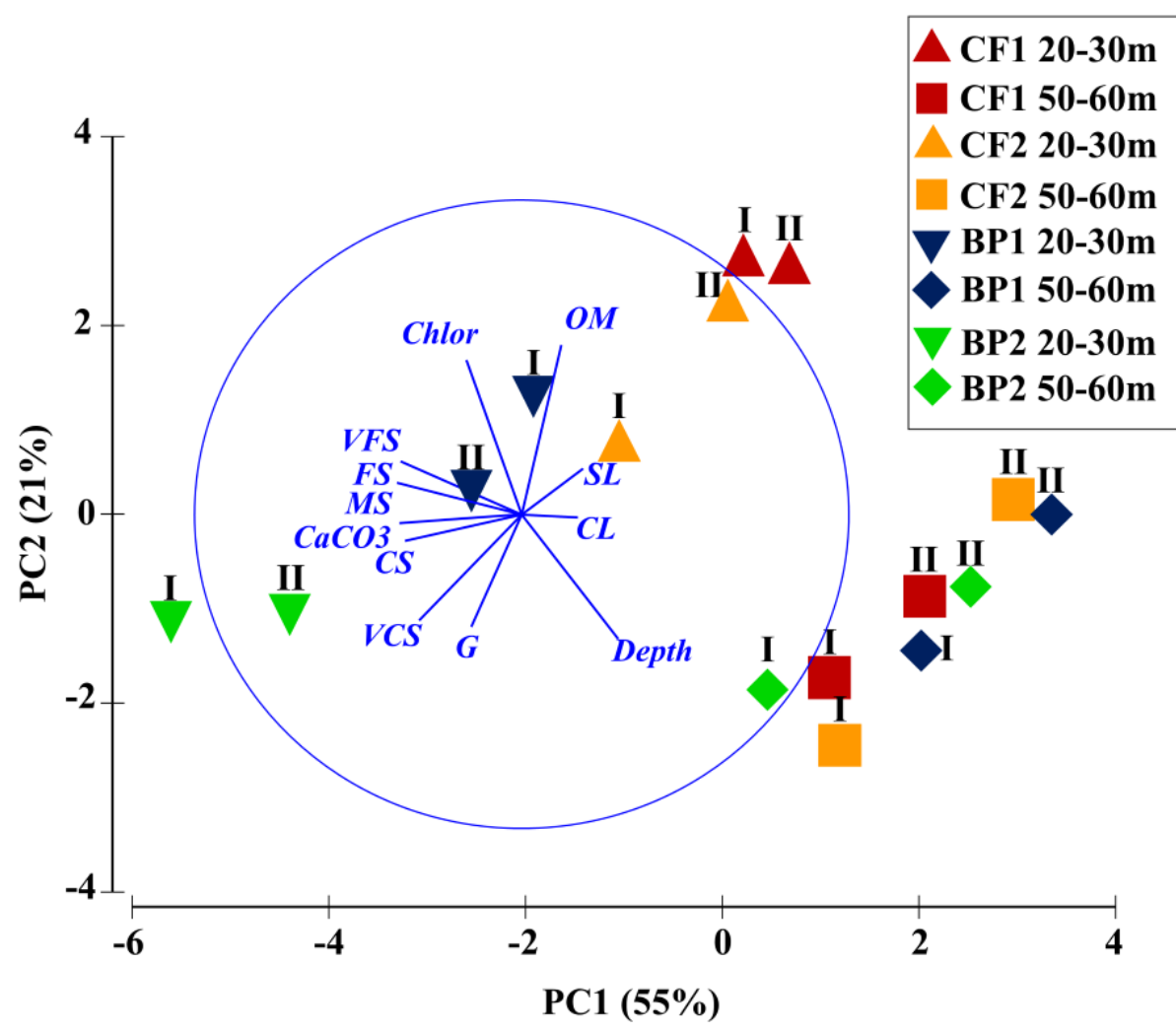

Figure 2. Principal component analysis (PCA) of the environmental variables measured at all sampled sites, depths, and periods (I or II). Vector plots indicate the direction and size of the correlation between PC axes and variables. Percentages of gravel (G); very coarse sand (VCS); coarse sand (CS); median sand (MS); fine sand (FS); very fine sand (VFS); silt (SL); clay (CL); carbonates $\left(\mathrm{CaCO}_{3}\right)$; organic matter (OM) and chlorophyll a (Chlor) in the sediment. 
PCA are in accordance with the obtained by the Spearman rank correlation analysis. Sand fractions and carbonates were negatively correlated with depth, silt, and clay, while positively correlated with chlorophyll-a and among them (Table SII).

\section{Meiofauna community structure}

Total meiofauna densities varied from 7,028 \pm 1,529 to $16,245 \pm 12,282$ inds. $10 \mathrm{~cm}^{-2}$ at $20-30 \mathrm{~m}$, and from $1,569 \pm 928$ to $7,088 \pm 1,338$ inds. $10 \mathrm{~cm}^{-2}$ at 50-60 m (Figure 3a). A total of 15 taxa were found. Nematoda was dominant (>90\%), followed by Nauplii and Copepoda at 20-30 m (98.7\%,
$0.6 \%$ and $0.4 \%$, respectively), together with Kinorhyncha at 50-60 m (91.0\%, 2.9\%, 2.7\% and $2.3 \%$, respectively). Polychaeta and Ostracoda occurred at both depths, while Turbellaria, Bivalvia, Gastrotricha and Oligochaeta occurred mainly at 20-30 m (Figure 3b). Other taxa were Anthozoa, Acarii, Amphipoda, Tanaidacea and Priapulida larvae, with extremely low densities.

Regarding spatial variation between sites, there were no statistical differences in total meiofauna and taxa densities in any of the sampling periods ( $\mathrm{KW}$ analysis were not significant). However, its notable that CF1 at 20-30 m had higher dominance of Nematoda

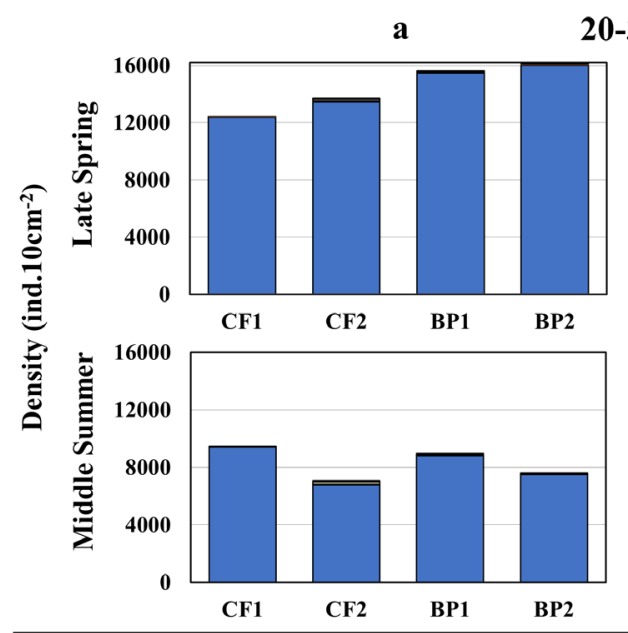

20-30 m
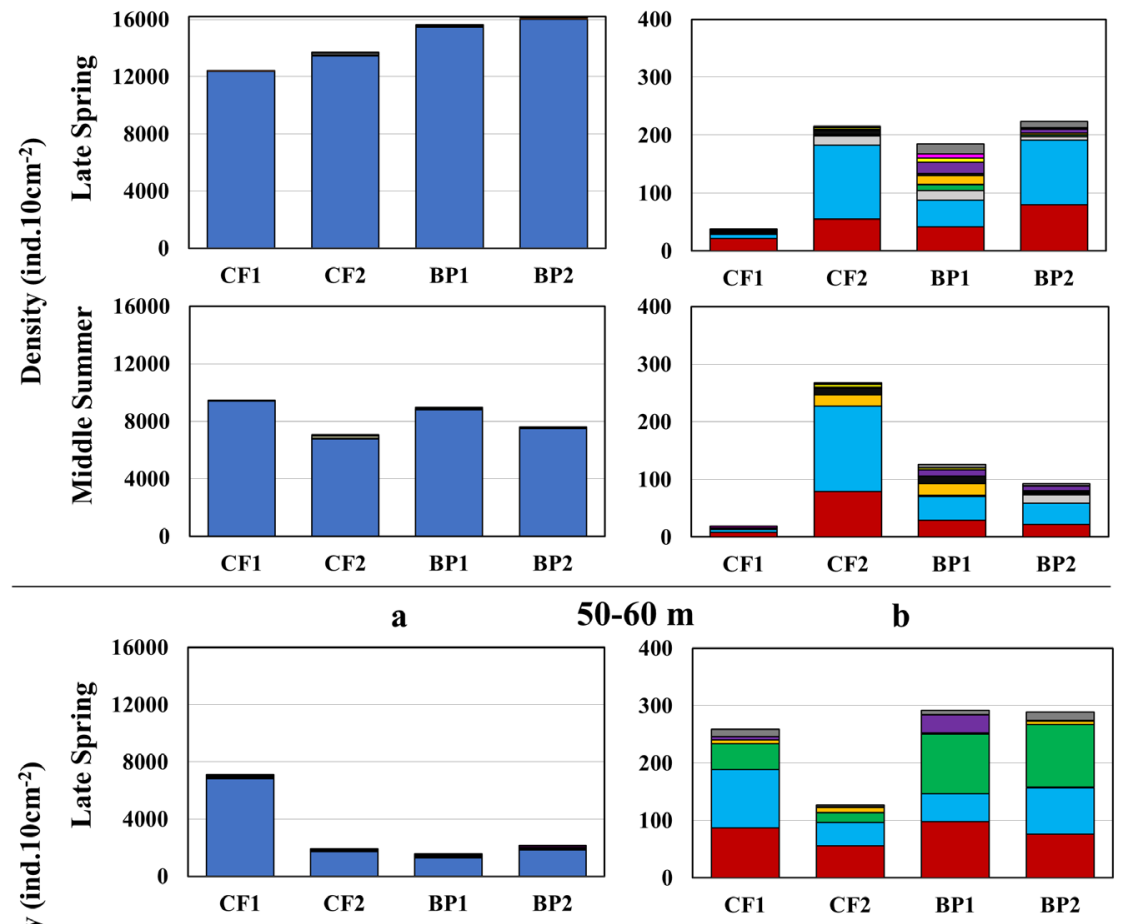

50-60 m
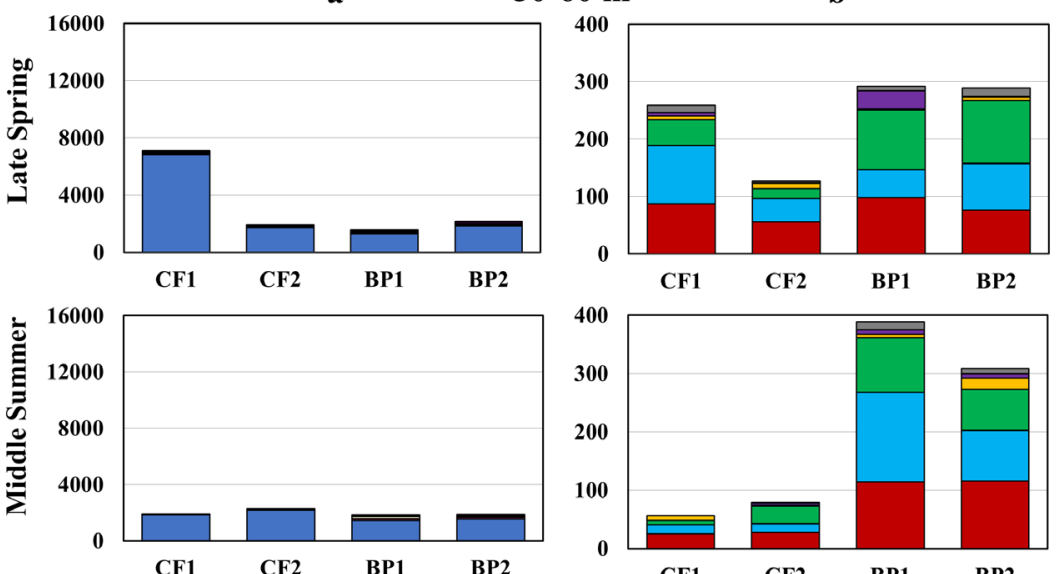

Figure 3. Mean densities (ind. $10 \mathrm{~cm}^{-2}$ )

of meiofauna taxon at each site, depth, and period. (a) showing all taxa; (b) removing Nematodes, to better visualize less dominant taxa distribution.

\begin{tabular}{llll}
$\square$ Copepoda & $\square$ Nauplii & $\square$ Turbellaria & $\square$ Kinorhyncha \\
$\square$ Polychaeta & $\square$ Gastrotricha & $\square$ Ostracoda & $\square$ Bivalvia \\
$\square$ Oligochaeta & $\square$ Other & $\square$ Nematoda & \\
\hline
\end{tabular}


than the other sites, with very low abundance of other taxa. Contribution of other taxa, except Nematoda, was higher at BP than at CF, at 50-60 $\mathrm{m}$, especially in middle summer (Figure $3 \mathrm{~b}$ ).

Between depths, total meiofauna and Nematoda densities were always lower at 50-60 $\mathrm{m}$ than at 20-30 m, being statistically significant at CF2 I, BP1 I, BP2 I, CF1 II, and CF2 II, and also at BP2 II for Nematoda only (MW, p < 0.05) (Table SIII). Copepoda densities varied greatly but had significantly higher densities at 50-60 m than at 20-30 $\mathrm{m}$ at CF1 I and BP1 II and BP2 II. Kinorhyncha also had higher densities at 50-60 $\mathrm{m}$ than at 20$30 \mathrm{~m}$, being significantly different at CF1 I, BP2 I, CF2 II and BP1 II (MW, p < 0.05). Nauplii densities were significantly higher at 50-60 m at CF1 I and BP1 II, but were higher at 20-30 m at CF2 I.

In terms of temporal variation, at 20-30 m, total meiofauna and Nematoda densities were higher in late spring than in middle summer, but differences were not significant due to high heterogeneity among replicates. That was also observed and was statistically different at BP2 for Copepoda and at CF2 for Kinorhyncha (MW, $\mathrm{p}<0.05$ ) (Table SIII). At 50-60 m, no differences were observed for total meiofauna or Nematoda between periods. Nevertheless, for Copepoda and Nauplii, densities were significantly higher in late spring than in middle summer at CF1 (MW, p < 0.05). Only Polychaeta at BP1 had higher densities in middle summer than in late spring (MW, $\mathrm{p}<0.05$ ).

The nMDS ordination separated samples by depth into two groups. Overlaying CLUSTER results with SIMPROF test showed each group had more than $80 \%$ similarity each (Figure 4). Only CF1 I 50-60 m was grouped with the 20-30 $\mathrm{m}$ samples, because it also had high densities. The 50-60 m samples were grouped by areas with $85 \%$ similarity, with lower dominance of nematodes at BP (79-86\%) than CF (93-97\%), and higher contribution of Kinorhyncha, Nauplii

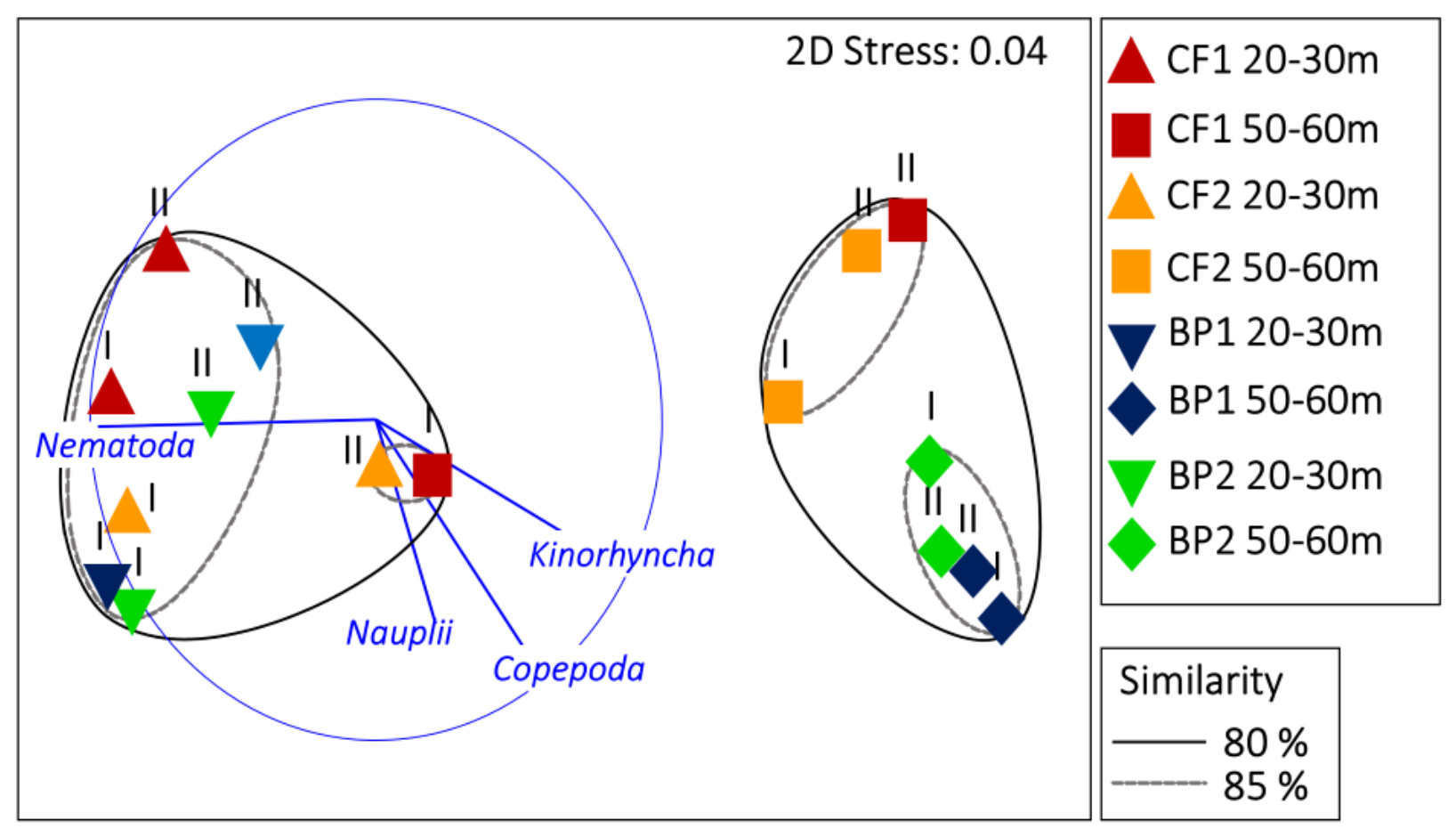

Figure 4. Non-metric multidimensional scaling (nMDS) for mean density of meiofauna taxa at all sites, depths, and periods (I - spring or II - summer). Vector plots indicate the direction and size of the correlation between axes and taxa. Data was square rooted, and Bray-Curtis resemblance measure was applied. 
and Copepoda (Figure 4). ANOSIM analysis with areas and depth showed composition was significantly different for all groups (Global test R:0.466, p:0.001), except between CF and $\mathrm{BP}$ at 20-30 m. SIMPER showed within group similarities higher than $70 \%$, and main taxa contributing for dissimilarities were Nematoda, with higher contribution at 20-30 m and at CF, while Copepoda and Kinorhyncha had higher contribution at 50-60 $\mathrm{m}$ and at BP (Table SIV).

Total meiofauna, Nematoda, Gastrotricha, Turbellaria, Bivalvia and Oligochaeta densities were positively correlated with sand fractions, carbonates, chlorophyll-a and phaeopigments, and negatively correlated with depth. Kinorhyncha densities showed an opposite pattern, while Copepoda, Nauplii, Polychaeta and Ostracoda did not show significant correlation with the measured environmental variables (Table SII).

\section{Nematoda community structure}

A total of 65 genera and 3 subfamilies, belonging to 24 families, were recorded (in 3436 specimens identified). These three subfamilies were not resolved to genus level and were considered one genus each for analysis and counting proposes hereafter. All taxa, average abundance (\%), trophic group assigned, and c-p values are listed in the Table SV.

Considering nematode community structure, cluster analysis for 30 main nematode genera densities distinguished shallower samples from deeper ones (R-mode) (Figure 5), with each group having a similarity greater than 60\% (SIMPROF). Comparing across genera dendrogram (Q-mode) and genus densities three main groups can be distinguished. Aponema, Daptonema, Dichromadora, Halalaimus, Sabatieria and Sphaerolaimus were the most abundant genera and occurred at both depths. These genera represented more $80 \%$ of the nematodes and were grouped with more than $70 \%$ similarity, but with higher abundances at 20-30 m. Acantholaimus, Prochromadorella, Chromadorita, Aegialoalaimus, Paramononhystera and Promonhystera were also abundant at 20-30 m, but less abundant at 50-60 m, and grouped with 55\% similarity. Most of these genera were positively correlated with sand fractions and chlorophyll-a, and negatively correlated with depth (Table SII). Actinonema, Dorylaimopsinae, Marylynnia, Molgolaimus, Comesomatinae, Metalinhomoeus, Linhomoeus, Oxystomina and Southerniella were more abundant at 50-60 m, and grouped with 50\% similarity, but represented less than $5 \%$ of the organisms. The first four were negatively correlated with sand fractions, and Molgolaimus was also negatively correlated with chlorophyll-a. Actinonema, Molgolaimus and Oxystomina were positively correlated with depth (Table SII).

ANOSIM analysis with pairwise comparisons among areas and depth showed genera composition was significantly different between all groups (Global test R:0.801, p:0.001), except between CF and BP at 50-60 m. SIMPER analysis results, showing genera that mostly contributed to total dissimilarity between groups are reported in Table SIV. No difference between periods was found. Between depth, at CF, Odontophora, Prochromadorella and Sabatieria were characteristic of the 20-30 m, while Southerniella and Molgolaimus were characteristic of the 50-60 m. At BP, Aponema and Prochromadorella were characteristic of the 20-30 m, while Molgolaimus and Marylynnia were characteristic of the 50-60 m. At 20-30m, between areas, Odontophora and Linhomoeus were characteristic of CF, while Aegialoalaimus and Chromadora were characteristic of BP. At 50$60 \mathrm{~m}$, although differences between areas were not significant, Aponema and Comesomatinae contributed more at CF, while Actinonema and 

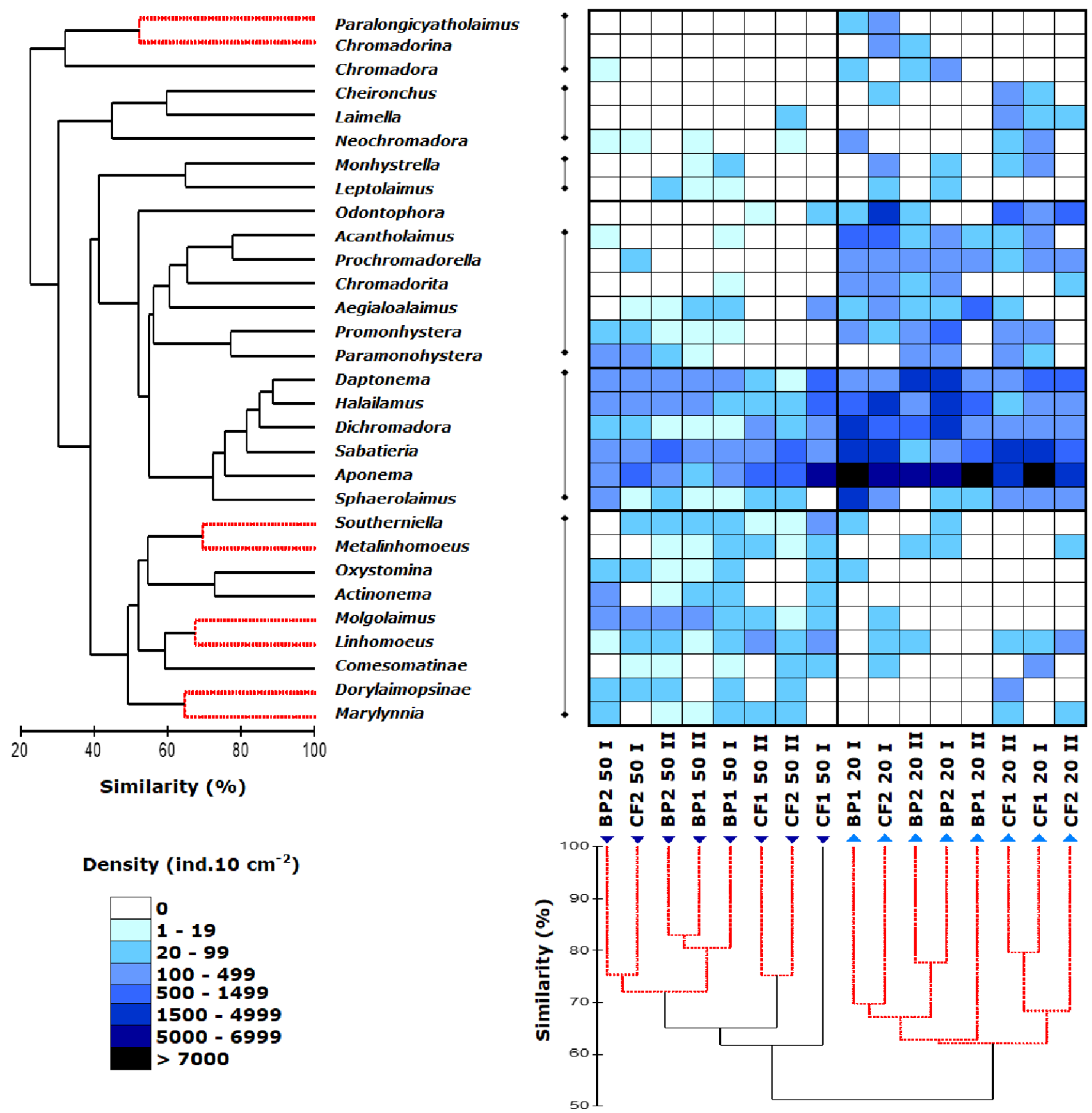

Density (ind. $10 \mathrm{~cm}^{-2}$ )

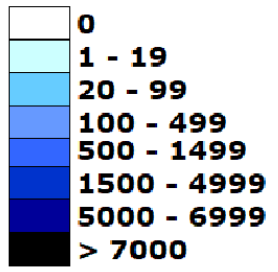

Figure 5. Dendrograms from Q-mode (across genera) and R-mode (across samples) hierarchical cluster analysis (group average linkage) based on Bray-Curtis similarity resemblance matrix for densities of the $\mathbf{3 0}$ most abundant genera of Nematoda (data was fourth rooted). Colored squares indicate genera mean densities in the sample (ind. $10 \mathrm{~cm}^{-2}$ ). I - spring or II - summer.

Promonhystera contributed more at BP (Table SIV).

Diversity ranged from $1.4 \pm 0.5$ to $3.6 \pm 0.2$ bits/ind (Figure $6 \mathrm{c}$ ), while evenness ranged from $0.48 \pm 0.19$ to $0.80 \pm 0.03$ (Figure $6 \mathrm{~d}$ ). Number of genera ranged from $8 \pm 1$ to $26 \pm 1$ per sample
(Figure 6e). No differences were observed between periods or between sites at 20-30 m. However, at 50-60 m, diversity values were higher at BP (23 \pm 3 genera per sample, $3.4 \pm 0.3$ bits/ind), and lower at CF $(15 \pm 3$ genera per sample, $2.3 \pm 0.8$ bits/ind), showing a clear difference between 

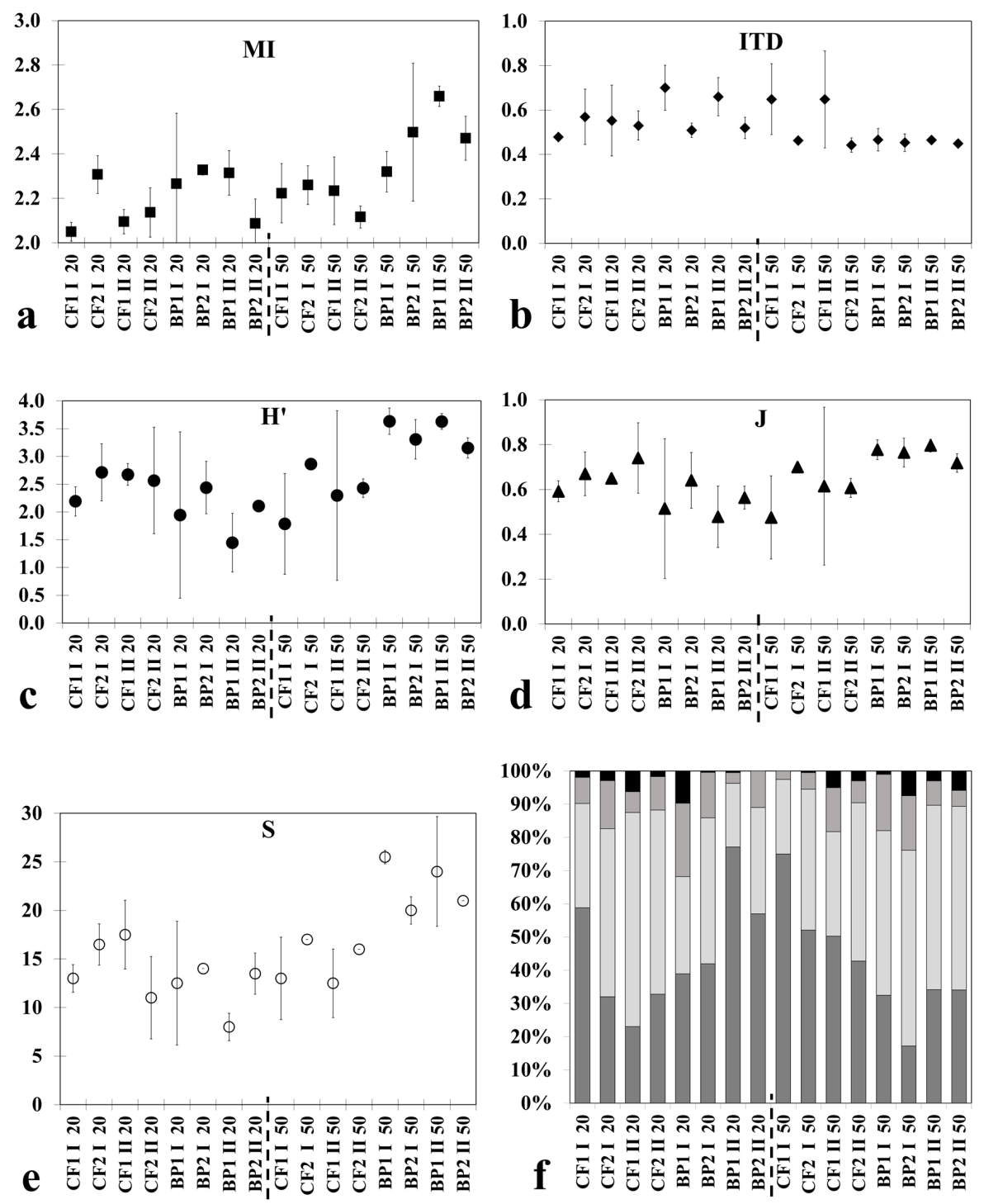
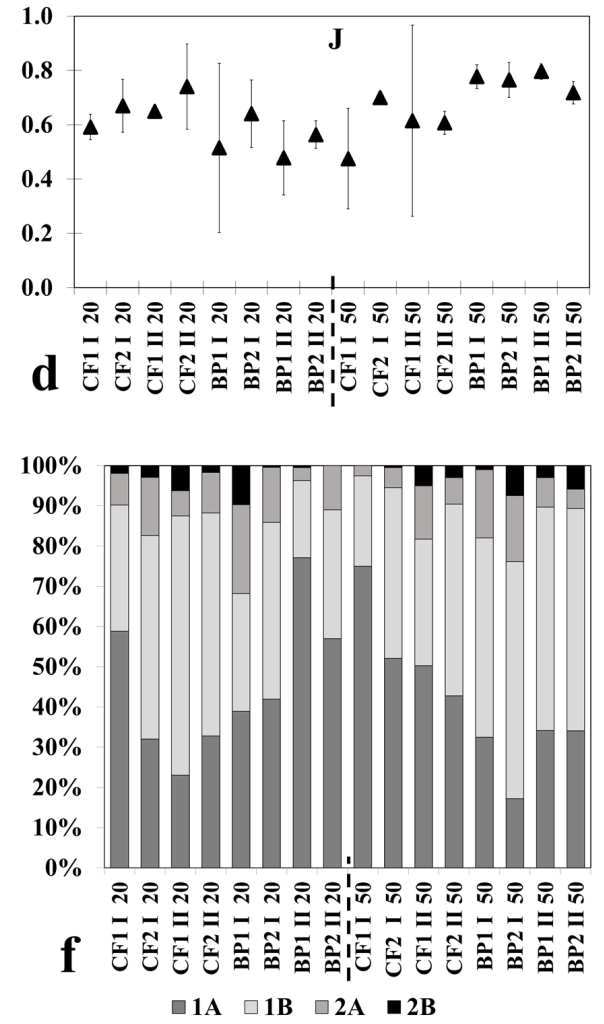

Figure 6. Biodiversity and trophic indexes (mean and standard deviation) for the nematode assemblage at each site, depth, and period (a) Maturity Index (MI); (b) Index of Trophic Diversity (ITD), (c) Shannon Diversity $\left(\mathrm{H}^{\prime}\right)$; (d) Pielou Eveness (J); (e) Richness as number of genera per sample (S); (f) frequency of each trophic group (1A- selective deposit feeders; 1B- non-selective deposit feeders; $2 A$ - epistrate feeders; 2B-predators/ omnivores). areas at this depth. No significant differences were observed due to great variance and low replication. In contrast with the pattern found for total meiofauna and Nematoda densities, richness diversity and evenness were negatively correlated with sand fractions, while richness was also positively correlated with depth and silt (Table SII).

Maturity index ranged from $2.05 \pm 0.04$ to $2.66 \pm 0.05$, with higher value at BP 50-60m (Figure $6 a)$, but not statistically significant. Trophic diversity ranged from $0.44 \pm 0.03$ to $0.70 \pm 0.1$ with lower values at BP 50-60 m, but not statistically significant (Figure 6f). The most frequent trophic groups were $1 \mathrm{~A}$ (from 18 to $79 \%$ ) and $1 \mathrm{~B}$ (from 19 to $66 \%$ ), followed by $2 \mathrm{~A}$ (from 3 to $26 \%$ ), while $2 \mathrm{~B}$ had very low frequency (from 0 to $12 \%$ ) (Figure 6f). Trophic groups and MI did not correlate significantly with the environmental variables. ITD correlated in a similar pattern as most abundant genera and nematoda abundance, with significative values with sand fractions and chlorophyll-a, while negative with depth (Table SIV). 


\section{DISCUSSION}

\section{Meiofauna community structure}

Meiofauna densities described in the present study are amongst the highest registered for Antarctic shallow water. Mean densities were 11,366 and 2,561 ind.10 $\mathrm{cm}^{-2}$, at 20-30 $\mathrm{m}$ and 50-60 $\mathrm{m}$ respectively. A comparative table with studies from Antarctic regions can be found in the Table SVI. High densities were also recorded previously in King George Island (Skowronski et al. 1998, Skowronski \& Corbisier 2002, Lee et al. 2003) and Signy Island (Vanhove et al. 1998, 2000). In contrast, very low densities were also registered in King George Island (Hong et al. 2011) and Signy Island (Lee et al. 2001a). However, these low densities registered were related to areas recently impacted by ice-scouring (Skowronski et al. 1998, Lee et al. 2001a, Hong et al 2011), which was not observed during the present study.

Regarding meiofauna community spatial variation, a clear separation between depths was observed, mostly driven by decrease nematode abundances with increasing depth. Depth variation was also observed for environmental variables and meiofauna taxa densities correlated significantly with these differences. Chlorophyll-a and organic matter percentages were higher at 20-30 m. Grain size differed between areas, while BP had more heterogeneous sediments and higher percentages of sands, CF had muddier sediments. The decline of sediment chlorophyll-a values with depth is an expected pattern, since microalgae primary production depends on light incidence for development (Cahoon 1999, McMinn et al. 2004). Previous studies in Martel Intel (Skowronski et al. 2009) also describe high concentration in the shallow, with steep decline below $40 \mathrm{~m}$. The present results agree with those already described in Martel Inlet (Skowronski \& Corbisier 2002) and other shallow water Antarctic zones (Vanhove et al. 1998, 2000) that high microphytobenthic biomass is possibly the main food source sustaining the high meiofauna densities found in these areas. Carbon stable isotopic analysis in Martel Inlet food web verified the coupling of meiofauna with microphytobenthic organic matter (Corbisier et al. 2004).

Although environmental characteristics were similar between areas at 50-60 m, with more fine sediments and lower contributions of sand fractions and chlorophyll-a, meiofauna composition differed between areas due to lower dominance of nematodes at BP. Nematodes can be more resilient to pollution than copepods, and we could speculate that this difference is a result of anthropogenic impact near EACF. However, studies with meiofauna major taxa and pollution are unconclusive, and both increase and reduction in abundances have been reported (Coull \& Chandler 1992, Giere 2009, and references therein). Apart from the difference described above, meiofauna densities and composition showed expected distribution and correlations with the measured environmental variables, therefore no indication of anthropogenic impact is suggested.

Regarding temporal variation, no evidence of increased anthropogenic impact from EACF was found between late spring and early summer. A cumulative impact due to increased activities throughout the summer at the station could be expected. However, few differences were observed between seasons and seemed more related to environmental factors. There are few studies on seasonal variations of meiofauna communities in the Antarctic region. An 18-month survey at Signy Island (Factory Cove, South Orkneys, Antarctica) revealed a complex temporal pattern, primarily regulated by availability of food sources, which is not limiting even in winter (Vanhove et al. 2000). A nine-month study on the meiofauna 
from Marian Cove (King George Island) during summer and winter periods, found densities increased from January to May, and from August to October, with higher densities in summer, but had peaks in densities even in colder periods. However, no correlation with physical and biological environmental factors measured (OM, particulate matter, chlorophyll, temperature, salinity) was found (Lee et al. 2003). Skowronski \& Corbisier (2002) studied meiofauna communities from seven sites in Martel Inlet (including CF) for two summer periods. Despite clear differences in hydrological condition and sediment deposition between years, no effects on meiofauna densities or composition were found. Barbosa et al. (2010) studied polychaetes distribution between early and late summer 2003 near EACF at similar depths as the present study and concluded that the slight differences found seem to be more related to natural impacts than to more intense human activities at the research station itself.

\section{Nematoda community structure}

The number of genera registered in the present study for Martel Inlet was high (44 for 20-30 $\mathrm{m}$ and 61 for 50-60 m). Comparison with other studies should be done with care, as increased genera richness is highly influenced by greater sampling effort. We resumed available studies in Table SVI. Values were similar to previous studies in Martel Inlet, at $15 \mathrm{~m}$ depth, which registered 58 and 76 genera in two consecutive years in seven areas (R.S.P. Skowronski, unpublished data). While, in East Antarctic, between 5 and $20 \mathrm{~m}$ depth, 38 nematode genera were recorded near Casey Station (Stark et al. 2020). Also, at Factory Cove, in Signy Island, around $10 \mathrm{~m}$ depth, number of genera registered varied from 19 to 49 (Vanhove et al. 1998, 2000, Lee et al. 2001a). Possibly, wider depth range in the present study contributed with the higher diversity observed in this comparison, as nematode diversity is generally much higher in Antarctic shelf waters. Some studies in deeper areas of the Antarctic continental shelf have reported higher genera diversities, such as 158 genera in Weddell Sea(211-2080 m) (Vanhove et al. 1999) and 94 genera in Scotia Sea (700-6000 m) (Vanhove et al. 2004). Raes et al. (2010) found 80 genera in shelf waters of the Larsen ice-shelf area (200 $-400 \mathrm{~m}$ ) and, Hauquier et al. (2011) found 66 nematode genera in a supposedly impoverished Larsen Ice Shelf area (800 m), which had only recently become ice free. Concluding, as number of genera is very variable and can be influenced by depth and sampling/identification effort, and since number of samples is low in this study, we can state that richness in Martel Inlet is high compared to other shallow water studies in Antarctica.

Nematode genera assemblages mainly distinguished shallower samples from deeper ones, however not by the dominant genera, but by subdominant ones at 50-60 m, which can be explained by natural changes in environmental factors. In Martel inlet, between areas at 20-30 $\mathrm{m}$, we can highlight, supported by the SIMPER analysis, the shift between Odontophora at CF to Chromadora at BP. It is possible that these genera are competing to occupy the same niche. Dominant genera composition was similar to the ones described by for Martel Inlet (R.S.P. Skowronski, unpublished data) and for other Antarctic shallow water regions (Vanhove et al. 1998, 2000, Pasotti et al. 2014) (Table SVI). Aponema or Microlaimus, Daptonema, Dichromadora or other Chromadoridae genera, Odontophora and Sabatieria were commonly found in those shallow coastal areas. The main difference in composition was found comparing our data with the area near Casey Station (Stark et al. 2020) were high abundance of Monhystera and Neochromadora was reported, with low 
abundance of Aponema and Dichromadora. In contrast, in deeper areas (> 200 m depth), Monhysteridae, Daptonema, Halalaimus, Molgolaimus or Microlaimus were more characteristic (Vanhove et al. 1999, 2004, Raes et al. 2010, Pantó et al. 2021).

Trophic diversity (ITD) is lowest when all feeding types are equally present (e.g. ITD = 0.25 ) and highest when only one trophic type is present (e.g. ITD = 1). Nematode trophic groups frequency in Martel Inlet, with dominance of selective deposit feeders ( $60 \%)$, were similar to those described for Antarctic shallow waters. Pasotti et al. (2012) analyzed the trophic structure of nematodes in the shallow coastal region of Signy Island during summer and winter, describing a dominance of selective deposit feeders ( $1 A, 38 \%)$, followed by epistrate feeders (2A, 30\%) and non-selective deposit feeders (1B, $25 \%)$, and low contribution of predators (2B, $5 \%$ ), in general. Feeding habit of Aponema, a dominant genus, is not well known, and based on buccal morphology it has been classified as selective deposit feeder (present study, Vanhove et al. 1999, Skowronski, unpublished data) or epistrate feeder (Vanhove et al. 1998, 2000, Pasotti et al. 2012, Losi et al. 2021). In these studies, high densities of Aponema were always linked to availability of fresh organic matter and benthic algae, in accordance with the correlations and distribution described here. Conversely, since Aponema densities were still high at 50-60 $\mathrm{m}$ in Martel Inlet, a more generalist feeding habitat of this genus should be expected, so we choose to classify it as selective deposit feeder (1A). As it is a dominant genus in coastal studies in Antarctica, this choice will influence the frequency of the trophic groups, so if Aponema was classified as epistrate feeder the frequency of $2 \mathrm{~A}$ would be higher, and $1 \mathrm{~A}$ would be lower. Thus, the designation to a feeding group should be carefully considered and informed when comparing trophic groups between different studies. Daptonema, classified as non-selective deposit feeders, can use different feeding strategies and adapts to change in very short time scale, feeding on diatoms, bacteria or flagellates (Vanhove et al. 2000). This opportunistic genus has a widespread distribution and is commonly abundant in Antarctic meiofauna (Pasotti et al. 2012, Stark et al. 2020). The high densities of Daptonema found throughout all samples in the present data are in accordance with this flexible feeding habit. There are also doubts about the trophic position of Acantholaimus, here classified as persisters $(c-p=3)$ and epistrate feeders $(2 A)$. This is a typical deep-sea genus that usually increases in abundance with depth, as has been negatively correlated with chlorophyll (De Mesel et al. 2006), so its feeding habit based on buccal morphology (Wieser 1953) has been questioned. However, our findings support the classification as epistrate feeders, as positive correlations with chlorophyll-a and higher abundance at 20$30 \mathrm{~m}$ were found.

The maturity index is based on the proportion of colonizer and persistent nematode genera in the sample. Genera are classified in $c-p$ values, where extreme colonizers $(c-p=1)$ represent those with shorter generation time and rapid recovery from stress, which are more tolerant of environmental variations ( $r$-strategist). In contrast, extreme persisters ( $c-p=5)$ are those with long generation time, which are more sensitive to stress (k-strategist) (Bongers et al. 1991). Shifts in the MI may reflect deterioration or recovery of a nematode assemblage and, thus the health of the surrounding habitat. Studies suggest that the $\mathrm{MI}$ is decreased by pollution (sewage waste, oil, heavy metals), but increases during the colonization processes (Bongers et al. 1991). In Signy Island, during a six months recolonization after physical impact study (Lee et al. 2001a), a MI of 2.1 was calculated and little 
change between sampling periods was found. The authors suggest that this low and stable values are a result of community adaptation through natural selection to a region frequently disturbed by ice. These values are very similar to the ones reported in Martel Inlet at 20-30 m. In a deeper area in the Weddell Sea, MI index of less than 2 to 2.5 was described for physical disturbed and undisturbed sites, respectively (Lee et al. 2001b). The values found in the present study in Martel Inlet are in the range of those reported. Although the values varied, a pattern was not very clear, and no significant variation or correlation was found. The only tendency that can be observed is at 50-60 $\mathrm{m}$ a higher mean value in BP (2.5) when compared to CF (2.2) (Figure 6a). This may indicate that the nematode community in CF is under higher stress than at BP. Future monitoring should investigate this further to confirm a possible impact.

In a study conducted near Casey Station, dominant genera were Monhystera, Daptonema, Neochromadora, Odotophora and Halalaimus. Also, Promonhystera, Paralinhomoeus and Pierrickia were consistently more abundant at polluted areas than at controls, while Daptonema, Halalaimus and Microlaimus were more abundant at controls (Stark et al. 2020). Such evident change in composition between areas was not found in the present study, so we are not able to indicate genera probably linked to polluted or control sites. However, richness and diversity at 50-60 $\mathrm{m}$ at CF was lower than BP. The difference was due to rare genera, since of the 61 genera registered at 50-60m, 19 occurred only at BP and one occurred only at CF, while 41 occurred at both areas. Of the dominant genera, main difference was in Aponema, that had higher densities in CF than BP. Differences in diversity and composition in the 50-60 m samples could not be explained by the measured environmental variables, like grain size or food availability, since they were homogeneous. Higher anthropogenic contamination could explain the reduced diversity at CF at this depth. Metals and hydrocarbons have been shown to cause negative effects in laboratory essays, and reductions in diversity and abundance of meiofauna in field studies (Coull \& Chandler 1992 and references therein). In a field experiment near Casey Station (East Antarctica) negative effect of hydrocarbon was recorded for meiofauna and nematodes diversity, that were likely to persist for more than five years showing little recovery in community structure (Stark et al. 2017). A recent review on studies using nematodes as bioindicators calculated sensibility scores for each taxon and disturbance category, where negative values indicate sensitivity and positive values, tolerance (Ridall \& Ingels 2021). Hydrocarbons, heavy metals, organic enrichment and chemical pollution were the most related to negative effects on nematodes. Of the dominant taxa found reported in Martel Inlet, Sabatieria, Daptonema, and Molgolaimus are classified as tolerant to pollution, while Aponema, Chromadorita and Prochromadorella are sensitive. However, scores for sensitivity were low, so the use of these genera as bioindicators to monitor pollution in for Martel Inlet is limited.

Concentrations of fecal sterols measured in the summer 2003/2004, year before the present sampling were $0.95 \mu \mathrm{g} . \mathrm{g}^{-1}$ at $10-20 \mathrm{~m}$ depth near EACF sewage outfall (Martins et al. 2012), values above background values $\left(0.19 \mu \mathrm{g} . \mathrm{g}^{-}\right.$ 1) (Montone et al. 2010). Values of $1.28 \mu \mathrm{g} \cdot \mathrm{g}^{-1}$ and $0.85 \mu \mathrm{g} . \mathrm{g}^{-1}$ have been reported for the vicinity of other Antarctic stations (Martins et al. 2012). Higher concentration of polycyclic aromatic hydrocarbonsPAHs) is found near EACF when compared to other areas in Admiralty Bay (Martins et al. 2004). Values were higher at $50 \mathrm{~m}$ (143 ng. $\left.\mathrm{g}^{-1}\right)$ than at $20 \mathrm{~m}$ at CF $\left(86 \mathrm{ng} \cdot \mathrm{g}^{-1}\right)$, although 
the shallower value is closer to the sewer source, the grain size of these sediments could explain the accumulation of organic compounds and consequently the difference in concentrations (Martins et al. 2004), since higher contribution of mud favors contaminant accumulation in the sediment.

Sediment in front of EACF also contained high concentrations of trace metals ( $\mathrm{B}, \mathrm{Mo}, \mathrm{Pb}$, $\mathrm{V}, \mathrm{Zn}, \mathrm{Ni}, \mathrm{Cu}, \mathrm{Mg}$ and $\mathrm{Mn}$ ). Despite the evidence of contamination, some authors suggested environmental risk is low because of poor bioavailability of these pollutants (Santos et al. 2005). The influence of sewage, aliphatic and polycyclic aromatic hydrocarbons is punctual, observed only near EACF sewage outfall. However, genotoxic effects were described in Antarctic fish Trematomus newnesi (Van Ngan et al. 2007) exposed to seawater from the sewage discharge outlet and from near the fuel storage tanks from CF, in situ and in bioassays experiments, conducted between 2002 and 2004. Genotoxicity, measured as increased DNA damage to hemocytes, was also described for amphipods Gondogeneia antarctica sampled in these same areas in February 2012 (Rocha et al. 2015).

Despite low contamination levels, some differences in the fauna near CF were detected in the late spring 2004 and mid-summer 2005 at 50-60 m when compared to BP that could be caused by anthropogenic impact of the sewage outfall. Thus, continued monitoring of benthic communities and pollutants levels is recommended. Future monitoring investigations must follow up this finding and pursue better comprehension of this possible impact. Further investigations, with smaller timescales and better evaluation of environmental factors with a multidisciplinary approach, especially related to pollutions levels and quality of food sources, will contribute to increase understanding of these communities, helping to distinguish natural from anthropogenic change.

\section{Acknowledgments}

We would like to thank two reviewers for their helpful comments that were material in improving the manuscript. Special thanks to Dr Lucia Campos, coordinator of Benthos Project (GEAMB), for her helpful contribution in providing samples. We thank the staff of the Brazilian Antarctic Station and scientists from REDE2 for their collaboration, especially those involved in sampling. Financial support and scholarship for this project was provided by Conselho Nacional de Desenvolvimento Científico e Tecnológico (CNPq 550354/02-6 - REDE 2 - “Avaliação do conhecimento da estrutura das comunidades bentônicas para o gerenciamento ambiental da Baía do Almirantado" and Conselho Nacional de Desenvolvimento Científico e Tecnológico/CNPq 135186/2005-6). We are grateful for support of the Ministério da Ciência, Tecnologia e Inovações (MCTI), Ministério do Meio Ambiente (MMA) and Comissão Interministerial para os Recursos do Mar (CIRM). This work is part of the master dissertation of PFG (Gheller 2007) and is in line with the Universidade de São Paulo policy.

\section{REFERENCES}

ATCM XXVIII. 2005. Review of the Admiralty Bay Antarctic specially managed area management plan (ASMA $n$ 1), $31 \mathrm{p}$.

AYRES M, AYRES MJR, AYRES DL \& SANTOS AAS. 2005. BioEstat: Aplicações estatísticas nas áreas das ciências biomédicas, 4a a ed, Sociedade Civil Mamirauá, Imprensa Oficial do Estado do Pará, Pará, Brasil, 324 p.

BANG HW, KANG SH \& LEE W. 2005. Study on the community structure of meiofauna in Marian Cove, King George Island, Antarctica. Korean J Environ Biol 23(2): 191-199.

BARBOSA LS, SOARES-GOMES A \& PAIVA PC. 2010. Distribution of polychaetes in the shallow, sublittoral zone of Admiralty Bay, King George Island, Antarctica in the early and late austral summer. Nat Sci 2: 1155-1163.

BEZERRA TN ET AL. 2021. Nemys: World Database of Nematodes. Accessed at http://nemys.ugent.be on 202108-03. doi:10.14284/366.

BÍCEGO MC, ZANARDI-LAMARDO E, TANIGUCHI S, MARTINS CC, SILVA DAM, SASAKI ST, ALBERGARIA-BARBOSA ACR, PAOLO FS, WEBER RR \& MONTONE RC. 2009. Results from a 15-year 
study on hydrocarbon concentrations in water and sediment from Admiralty Bay, King George Island, Antarctica. Antarc Sci 21(3): 209-220.

BONGERS T, ALKEMADE R \& YEATES GW. 1991. Interpretation of disturbance-induced maturity decrease in marine nematode assemblages by means of the Maturity Index. Mar Ecol Prog Ser 76: 135-142.

BYERS SC, MILLS EL \& STEWART PL. 1978. A comparison of methods of determining organic carbon in marine sediments, with suggestions for a standard method. Hydrobiologia 8(1): 43-47.

CAHOON LB. 1999. The role of benthic microalgae in neritic ecosystems. Oceanogr Mar Biol 7: 47-86.

CLARKE KR \& GORLEY RN. 2006. PRIMER v6. User Manual/ Tutorial Plymouth Routine in Multivariate Ecological Research. Plymouth: Plymouth Marine Laboratory.

CONLAN KE, KIM SL, LENIHAN HS \& OLIVER JS. 2004. Benthic changes during 10 years of organic enrichment by McMurdo Station, Antarctica. Mar Pollut Bull 49: 43-60.

CORBISIER TN, GHELLER PF, UJIKAWA MCY, BROMBERG S \& PETTI MAV. 2010. Monitoring the impact of human activities in Admiralty Bay, King George Island, Antarctica preliminary results of the meiofauna community. Annual Activity Report - INCT /APA, Rio de Janeiro, p. 171-175. DOI: 10.4322/apa.2014.045.

CORBISIER TN, PETTI MAV, SKOWRONSKI RSP \& BRITO TAS. 2004. Trophic relationship in the nearshore zone of Martel Inlet (King George Island, Antarctica): d13 C stableisotope analysis. Polar Biol 27: 75-82.

COULL BC. 1988. Ecology of the marine meiofauna. In: Higgins RP \& Thiel $H$ (eds) Introduction to the study of meiofauna. Smithsonian Institution Press, Washington: DC, p. 18-38.

COULL BC \& CHANDLER GT. 1992. Pollution and meiofauna: field, laboratory, and mesocosm studies. Oceanog Mar Biol 30: 191-271.

DANOVARO R, PUSCEDDU A, MIRTO S \& FABIANO M. 1999. Meiofaunal assemblages associated with scallop beds (Adamussium colbecki) in the coastal sediments of Terra Nova Bay (Ross Sea, Antarctica). Antarc Sci 11: 415-418. DOI 10.1017/s0954102099000528.

DE GRISSE AT. 1969. Redescription ou modification de quelques techniques utilisées dans l'étude des nématodes phytoparasitaires. Mededelingen van de Rijksfakulteit Landbowwetenschappen. Gent 34: 351-369.

DE MESEL I, LEE HJ, VANHOVE S, VINCX M \& VANREUSEL A. 2006. Species diversity and distribution within the deep-sea nematode genus Acantholaimus on the continental shelf and slope in Antarctica. Polar Biol 29: 860-871. https://doi.org/10.1007/s00300-006-0124-7.

ECHEVERRÍA CA, LAVRADO HP, PAIVA PC \& CAMPOS LA. 2009. New mini box corer for sampling muddy bottoms in Antarctic shallow waters. Braz Arch Biol Technol 52(3): 629-636.

FABIANO M \& DANOVARO R. 1999. Meiofauna distribution and mesoscale variability in two sites of the Ross Sea (Antarctica) with contrasting food supply. Polar Biol 22: 115-123. doi: 10.1007/s003000050398.

FONSECA V, SINNIGER F, GASPAR J, QUINCE C, CREER S, POWER DM, PECK LS \& CLARK MS. 2017. Revealing higher than expected meiofaunal diversity in Antarctic sediments: a metabarcoding approach. Sci Rep 7: 6094.

GIERE O. 2009. Meiobenthology - The Microscopic Motile Fauna of Aquatic Sediments, $2^{\text {nd }}$ ed, Springer-Verlag Berlin Heidelberg, XVII, 527 p. DOI: 10.1007/978-3-540-68661-3.

GROSS MG. 1971. Carbon determination. In: Carver RE (Ed) Procedures in sedimentary petrology: New York, J Wiley \& Sons, p. 573-596.

HAUQUIER F, INGELS J, GUTT J, RAES M \& VANREUSEL A. 2011. Characterization of the nematode community of a lowactivity cold seep in the recently ice-shelf free Larsen B Area, Eastern Antarctic Peninsula. PLoS ONE 6(7): e22240. doi:10.1371/journal.pone.0022240.

HEIP C, VINCX M \& VRANKEN G. 1985. The ecology of marine nematodes. Ann Rev Mar Sci 23: 399-489.

HONG J, KIM K, LEE S, BACK J, LEE DJ \& LEE W. 2011. The community structure of meiofauna in Marian Cove, King George Island, Antarctica. Ocean Polar Res 33: 265-280. DOI 10.4217/opr.2011.33.3.265.

INGELS J, HAUQUIER F, RAES M \& VANREUSEL A. 2014. Chapter 5.1. Antarctic free-living marine nematodes. In: Broyer DEC et al. (Eds). Biogeographic Atlas of the Southern Ocean. Scientific Committee on Antarctic Research, Cambridge, p. 83-87.

JAZDZEWSKI K, JURASZ W, KITTEL W, PRESTER E, PRESTER P \& SICINSKI J. 1986. Abundance and biomass estimates of the benthic fauna in Admiralty Bay, King George Island, South Shetland Islands. Polar Biol 6: 5-16.

LEE HJ, GERDES D, VANHOVE S \& VINCX M. 2001b. Meiofauna response to iceberg disturbance on the Antarctic continental shelf at Kapp Norvegia (Weddell Sea). Polar Biol 24: 926-933. doi: 10.1007/s003000100301.

LEE HJ, VANHOVE S, PECK LS \& VINCX M. 2001a. Recolonization of meiofauna after catastrophic iceberg scouring in 
shallow Antarctic sediments. Polar Biol 24: 918-925. doi: 10.1007/s003000100300.

LEE W, KANG S, MONTAGNA PA \& KWAK I. 2003. Temporal dynamics and patterning of meiofauna community by self-organizing artificial neural networks. Ocean Polar Res 25(3): 237-247.

LENIHAN HS, OLIVER JN, OAKDEN JM \& STEPHENSON MD. 1990. Intense and localized benthic marine pollution around McMurdo Station, Antarctica. Mar Pollut Bull 21(9): 422-430.

LOSI V, GRASSI E, BALSAMO M, ROCCHI M, GAOZZA L \& SEMPRUCCI F. 2021. Changes in taxonomic structure and functional traits of nematodes as tools in the assessment of port impact. Est Coast Shelf Sci 206(5): 107524. doi: https://doi. org/10.1016/j.ecss.2021.107524.

MARE MF. 1942. A study of a marine benthic community with special reference to the micro-organisms. J Mar Biol Assoc UK 25: 517-554.

MARTINS CC, AGUIAR SN, BÍCEGO MC \& MONTONE RC. 2012. Sewage organic markers in surface sediments around the Brazilian Antarctic station: results from the 2009/2010 austral summer and historical tendencies. Mar Poll Bull 64: 2867-2870.

MARTINS CC, AGUIAR SN, WISNIESKI E, CESCHIM LMM, FIGUEIRA RCL \& MONTONE RC. 2014. Baseline concentrations of faecal sterols and assessment of sewage input into different inlets of Admiralty Bay, King George Island, Antarctica. Mar Poll Bul 78: 218-223.

MARTINS CC, BÍCEGO MC, ROSE NL, TANIGUCHI S, LOURENÇO RA, FIGUEIRA RCL, MAHIQUES MM \& MONTONE RC. 2010. Historical record of polycyclic aromatic hydrocarbons (PAHs) and spheroidal carbonaceous particles (SCPS) in marine sediment cores from Admiralty Bay, King George Island, Antarctica. Environ Pollut 158: 192-200.

MARTINS CC, BÍCEGO MC, TANIGUCHI S \& MONTONE RC. 2004. Aliphatic and polycyclic aromatic hydrocarbons in surface sediments in Admiralty Bay, King George Island, Antarctica. Antarct Sci 16(2): 117-122.

MARTINS CC, MONTONE RC, GAMBA RC \& PELLIZARI VH. 2005. Sterols and faecal indicator microorganisms in sediments from Admiralty Bay, Antarctica. Braz J Oceanogr 53(1-2): $1-12$.

MCMINN A, RUNCIE JW \& RIDDLE M. 2004. Effect of seasonal sea ice breakout on the photosynthesis of benthic diatom mats at Casey, Antarctica. J Phycol 40: 62-69.

MONTONE RC ET AL. 2013. Environmental Assessment of Admiralty Bay, King George Island, Antarctica. In: Verde C \& DI Prisco G (Eds) Adaptation and evolution in marine environments-the impacts of global change on biodiversity, vol 2. Springer, Heidelberg, 250 p.

MONTONE RC, MARTINS CC, BÍCEGO MC, TANIGUCHI S, SILVA DAM, CAMPOS LS \& WEBER RR. 2010. Distribution of sewage input in marine sediments around a maritime Antarctic research station indicated by molecular geochemical indicators. Sci Tot Environ 408: 4665-4671.

NONATO EF, BRITO TAS, PAIVA PC \& PETTI MAV. 1992. Programa Antártico Brasileiro: projeto "Bionomia da fauna bentônica Antártica”. Atividades subaquáticas realizadas na Baía do Almirantado a partir da VI Expedição (1988). Relat Int Inst Oceanogr Univ São Paulo. 33: 1-12.

PANTÓ G, PASOTTI F, MACHERIOTOU L \& VANREUSEL A. 2021. Combining traditional taxonomy and metabarcoding: Assemblage structure of nematodes in the shelf sediments of the Eastern Antarctic Peninsula. Front Mar Sci 8: 629706. doi: 10.3389/fmars.2021.629706.

PASOTTI F, CONVEY P \& VANREUSEL A. 2014. Potter Cove, west Antarctic Peninsula, shallow water meiofauna: a seasonal snapshot. Antarc Sci 26: 554-562. DOI 10.1017/ s0954102014000169.

PASOTTI F, DE TROCH M, RAES M \& VANREUSEL A. 2012. Feeding ecology of shallow water meiofauna: insights from a stable isotope tracer experiment in Potter Cove, King George Island, Antarctica. Polar Biol 35: 1629-1640. DOI 10.1007/s00300-012-1203-6.

PLANTE-CUNY MR. 1978. Pigments photosynthétiques et production primaire dês fonds meubles néritiques d'une region tropicale (Nosy-Bé, Madagascar). Trav Doc ORSTOM 96: 1-359.

R CORE TEAM. 2021. R: A language and environment for statistical computing. R Foundation for Statistical Computing, Vienna, Austria. http://www.R-project.org.

RAES M, ROSE A \& VANREUSEL A. 2010. Response of nematode communities after large-scale ice-shelf collapse events in the Antarctic Larsen area. Glob Change Biol 16(5): 1618-1631.

REVELLE W. 2021. psych: Procedures for Psychological, Psychometric, and Personality Research. Northwestern University, Evanston, Illinois. R package version 2.1.6, https://CRAN.R-project.org/package=psych.

RIDALL A \& INGELS J. 2021. Suitability of free-living marine nematodes as bioindicators: Status and future considerations. Front Mar Sci 8: 685327. doi: 10.3389/ fmars.2021.685327.

ROCHA AJS, BOTELHO MT, HASUE FM, PASSOS MJAC R, VIGNARDI CP, NGAN PV \& GOMES V. 2015. Genotoxicity of shallow waters near the Brazilian Antarctic station "Comandante 
Ferraz" (EACF), Admiralty Bay, King George Island, Antarctica. Braz J Oceanogr 63(1): 63-70. DOI 10.1590/ S1679-87592015080906301.

ROSE A, INGELS J, RAES M, VANREUSEL A \& ARBIZU PM. 2015. Long-term iceshelf-covered meiobenthic communities of the Antarctic continental shelf resemble those of the deep sea. Mar Biodiv 45: 743-762. doi: 10.1007/ s12526-014-0284-6.

SANTOS IR, SILVA-FILHO EV, SCHAEFER CEGR, ALBUQUERQUEFILHO MR \& CAMPOS LS. 2005. Heavy metal contamination in coastal sediments and soils near the Brazilian Antarctic Station, King George Island. Mar Poll Bull 50(2): 185-194.

SEINHORST JW. 1959. A rapid method for the transfer of nematodes from fixative to anhydrous glycerin. Nematologica 4: 67-69.

SICINSKI J ET AL. 2011. Admiralty Bay Benthos diversity: a long-term census. Deep Sea Res II 58(1-2): 30-48.

SIMÕES IC, ARIGONY NETO I \& BREMER UF. 2004. O uso de mapas antárticos em publicações. Pesq Antart Bras 4: 191-197.

SKOWRONSKI RSP \& CORBISIER TN. 2002. Meiofauna distribution in Martel Inlet, King George Island (Antarctica): sediment features versus food availability. Polar Biol 25(2): 126-134.

SKOWRONSKI RSP, CORBISIER TN \& ROBLES FR. 1998. Meiofauna along a coastal transect in Admiralty Bay, King George Island (Antarctica). Pesq Antart Bras 3(1): 117-131.

SKOWRONSKI RSP, GHELLER PF, BROMBERG S, DAVID CJ, PETTI MAV \& CORBISIER TN. 2009. Distribution of microphytobenthic biomass in Martel Inlet, King George Island (Antarctica). Polar Biol 32: 839-851. DOI 10.1007/s00300-009-0584-7.

STARK JS, MOHAMMAD M, MCMINN A \& INGELS J. 2017. The effects of hydrocarbons on meiofauna in marine sediments in Antarctica. J Exp Mar Biol Ecol 496: 56-73. DOI 10.1016/j.jembe.2017.07.009.

STARK JS, MOHAMMAD M, MCMINN A \& INGELS J. 2020. Diversity, abundance, spatial variation, and human impacts in marine meiobenthic nematode and copepod communities at Casey Station, East Antarctica. Front Mar Sci 7: 480. DOI 10.3389/fmars.2020.00480.

STARK, IS, RIDDLE MJ, SNAPE I \& SCOULLER RC. 2003. Human impacts in Antarctic marine soft-sediment assemblages: correlations between multivariate biological patterns and environmental variables at Casey Station. Estuar Coast Shelf Sci 56: 717-734.
SUGUIO K. 1973. Introdução a Sedimentologia. São Paulo. Edgard Blüecher, Editora Universidade de São Paulo, 317 p.

TIN T, FLEMING ZL, HUGHES KA, AINLEY DG, CONVEY P, MORENO CA, PFEIFFER S, SCOTT I \& SNAPE I. 2009. Impacts of local human activities on the Antarctic environment. Antarct Sci 21(1): 1-31.

TREVISANI TH, PETTI MAV, RIBEIRO AP, CORBISIER TN \& FIGUEIRA RCL. 2018. Heavy metal concentrations in the benthic trophic web of Martel Inlet, Admiralty Bay (King George Island, Antarctica). Mar Pollut Bull 130: 198-205.

VAN NGAN P, GOMES V, PASSOS MJACR, USSAMI KA, CAMPOS DYF \& ROCHA AJD. 2007. Biomonitoring of the genotoxic potential (micronucleus and erythrocyte nuclear abnormalities assay) of the Admiralty Bay water surrounding the Brazilian Antarctic Research Station "Comandante Ferraz," King George Island. Polar Biol 30: 209-217.

VANHOVE S, ARNTZ W \& VINCX M. 1999. Comparative study of the nematode communities on the south-eastern Weddell Sea shelf and slope (Antarctica). Mar Ecol Prog Ser 181: 237-256.

VANHOVE S, BEGHYN M, VAN GANSBEKE D, BROCKINGTON $S$ \& VINCX M. 1998. The metazoan meiofauna in its biogeochemical environment: the case of an Antarctic coastal sediment. J Mar Biol Assoc UK 78(2): 411-434. DOI $10.1017 /$ s0025315400041539

VANHOVE S, BEGHYN M, VAN GANSBEKE D, BULLOUGH L \& VINCX M. 2000. A seasonally varying biotope at Signy Island, Antarctic: implications for meiofaunal structure. Mar Ecol Prog Ser 202: 13-25. DOI 10.3354/meps202013.

VANHOVE S, VERMEERREN H \& VANREUSEL A. 2004. Meiofauna towards the South Sandwich Trench (750-6300m), focus on nematodes. Deep-sea Res II 51: 1665-1687.

WARWICK RM, PLATT HM \& SOMERFIELD PJ. 1998. Free living marine nematodes: part III. Monhysterids. In: Barnes RSK \& Crothers JH (Eds), Synopses of the British Fauna (new series), vol. 53. Field Studies Council, p. 1-303.

WIESER W. 1953. Die Beziehung zwischen Mundhöhlengestalt ,Ernährungsweise und Vorkommen bei freilebenden marinen Nematoden: eine ökologischmorphologische Studie. Arkiv för Zoologi 4: 439-484.

\section{SUPPLEMENTARY MATERIAL}

\section{Tables SI-SVI}




\section{How to cite}

GHELLER PF \& CORBISIER TN. 2022. Monitoring the anthropogenic impacts in Admiralty Bay using meiofauna community as indicators (King George Island, Antarctica). An Acad Bras Cienc 93: e20210616. DOI 10.1590/0001-3765202220210616.

Manuscript received on April 20, 2021;

accepted for publication on September 21, 2021

PAULA F. GHELLER

https://orcid.org/0000-0002-1455-1271

\section{THAIS N. CORBISIER}

https://orcid.org/0000-0001-7686-0654

Universidade de São Paulo, Instituto Oceanográfico,

Departamento de Oceanografia Biológica, Praça Oceanográfico,

191, Cidade Universitária, 05508-120 São Paulo, SP, Brazil

Correspondence to: Paula F. Gheller

E-mail: paulafgheller@usp.br

\section{Author contributions}

PFG carried out the analysis of data, preparation of tables and figures, and wrote the first draft of the manuscript. TNC supervised the findings of this work. All authors discussed results, wrote, and contributed to the final manuscript.

\section{(cc) BY}

